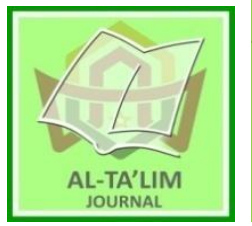

AL-TA'LIM JOURNAL, 26 (3), 2019, (280-297)

(Print ISSN 1410-7546 Online ISSN 2355-7893)

\title{
The Trends of Biology Education Research from 2000 to 2017: A Content Analysis for the Thesis of Pre-Service Teachers
}

Received: $27^{\text {th }}$ June 2019; Revised: $28^{\text {th }}$ October 2019; Accepted: $28^{\text {th }}$ November 2019

Permalink/DOI: http://dx.doi.org/10.15548/jt.v26i3.574

\section{Haviz ${ }^{*)}$}

Institut Agama Islam Negeri Batusangkar, Indonesia

E-mail: mhaviz@iainbatusangkar.ac.id

\section{Asma Dewi}

Universitas Negeri Padang, Indonesia

Email: asmadewi@gmail.com

\section{Arlita Laras Putri}

Institut Agama Islam Negeri Batusangkar, Indonesia

Email: arlitalarasputri@gmail.com

\section{Asri Wahyuni \\ Institut Agama Islam Negeri Batusangkar, Indonesia \\ Email: asriwahyuni@gmail.com}

\section{Najmiatul Fajar}

Institut Agama Islam Negeri Batusangkar, Indonesia

Email: najmiatulfajar@iainbatusangkar.ac.id

\section{Lufri}

Universitas Negeri Padang, Indonesia

Email: lufri@unp.ac.id

\begin{abstract}
This study aims to investigate the trend of biological education research (BER) from 2000 to 2017 in the thesis of pre-service biology teachers. This study conducted a series of content analyses of the thesis from two universities. A total 1347 thesis were analyzed in terms of sample, method, design, elements and topics and subject matter. It was found that junior and senior high school were the most popular research sample trends. This study was also found that quantitive, research and development or/and educational design research became the trend of the method most chosen and conducted by preservice biology teachers. The findings were also indicated that descriptive, experimental, and 4-D were design trends chosen by preservice biology teachers. This study was also found that cognitive and media of learning were the research elements are the most chosen and conducted by preservice biology teachers. The next findings showed that system and cell was the most popular of biology topic. This finding also indicated that Digestive System (DS) and Circulatory System (CS) and Features (KF) as the most chosen subject matter trends conducted by preservice teachers.
\end{abstract}

\section{*) Corresponding author}

Keywords: Trends; biology education research; content analysis; thesis of pre-service biology teacher.

How to Cite: Haviz, M., Dewi, A., Putri, A., Wahyuni, A., Fajar, N., \& Lufri, L. (2020). The trends of biology education research from 2000 to 2017: A content analysis for the thesis of pre-service teacher. Al-Ta Lim Journal, 26(3). doi:http://dx.doi.org/10.15548/jt.v26i3.574

\section{INTRODUCTION}

Research on the investigation of biology education research trends in universities was important to conducted by the reseachers in the field of biology education, besides research on learning in the 21st century (Haviz et al., 2018; Haviz et al., 2019), and the use of methods in biology learning (Haviz, 2019; Haviz and Maris, 2018; Haviz et al., 2018; Haviz, 2016, Haviz, 2015). There are many benefits obtained by conducting research on trends in biology education research at universities. The data 
obtained from this research can be used to map the direction and development of biology education research that has been done by preservice teachers at the university. A more in-depth study of this topic will also determine the obstacles faced by lecturers at the university. A more in-depth study of this topic is also needed to determine the direction and policy of research in the field of biology education which will be carried out by researchers at the university in the future. Even studies to investigate trends in biology education research will explore the status of researchers and the trends they are doing in biology education research (Gul \& Sozbilir, 2015). Some statuses are used as objects by researchers to determine research trends that come from theses or articles are methods, samples, research elements, topics and research subjects. Information about these five terms is needed by preservice biology teachers to write their research reports.

One way that can be done to collect these information scientifically is to do a content analysis (Elo \& Kyngas, 2008). Content analysis is a research technique for making replicable and valid inferences from texts (or other meaningful matter) to the contexts of their use (Krippendorff, 2004). Qualitative content analysis is one of numerous research methods used to analyze text data (Hsieh \& Shannon, 2005). Data migh be used in content analysis such as verbal, print, or electronic form, narrative responses, open-ended survey questions, interviews, focus groups, observations or print media such as articles, books, or manuals (Kondracki \& Wellman, 2002). Hsieh \& Shannon (2005) have identified three distinct approaches: conventional, directed, and summative. There are major coding differences among three approaches to content analysis. The characteristics of conventional content analysis; study starts with observation, codes are defined during data analysis and codes are derived from data. The characteristics of directed content analysis: study starts with theory, codes are defined before and during data analysis and codes are derived from theory or relevant research findings. The characteristics of summative content analysis: study starts with keywords keywords are identified before and during data analysis and keywords are derived from interest of researchers or review of literature (Hsieh \& Shannon, 2005).

Many previous researchers have conducted content analysis, for example Chang et al. (2010) has conducted quantitative content analysis of trends of science education research from four previously published articles, and they found that from 1990 to 2007 the most researched topics of science education research were conceptual change and concept mapping, number of publications declined slightly in 2000. The intended topics were professional development, the nature of science and socioscientific issues, and conceptual and analogous changes. The study also found that, the most widely quoted reference, the disciplines and theories supporting scientific education research are constructivist learning, cognitive psychology, pedagogy, and science philosophy. Derman (2017) has conducted quantitative content analysis to investigate the biology education research trend from student theses in Turkey from 1989-2015. The results of this study have shown that quantitative research methods are the most preferred method. The results of this study have also shown that the study population is taken from middle school students, the object of biological research that is most widely used is the environment, cells and living things and the least used object of biological research is tissue, evolution, organ systems and energy. Gul \& Sozbilir (2015) has analyzed quantitative and qualitative content on biology education research published in eight indexed journals on Thomson Reuters Social Science Citation Index [SSCI] from 19942014. The findings of this study show that there were 1376 articles investigated which have been found that the topics often examined are environment and ecology, genetics and biotechnology, and animal functions. These findings have also shown that learning, teaching and attitudes are frequently researched topics, middle and high 
school students are preferred as sample groups and sample sizes vary between 31 to 100 and 101 to 300 . In addition, in this study it has also been found that the design of interactive qualitative research is mostly preferred by researchers. In addition, a single data collection tool is generally used and this data collection tool includes questionnaires, interviews and documents.

Lee et al. (2009) also carried out quantitative content analysis of Research trends in science education from 2003 to 2007 in selected journals. Research conducted by Lee et. al (2009) is a follow-up of Tsai and Wen's (2005) initial research, this study found and analyzed 802 articles published in the International Journal of Science Education, Science Education, and the Journal of Research in Science Teaching from 1998 to 2002 The topics that have been analyzed are the author's nationality, type of research, and research topic. In this study, there were also 869 papers published in three journals from 2003 to 2007, and the results were compared with those of Tsai and Wen. In addition, this study also identified 31 widely cited papers in 1998 to 2002 and 20 papers with high titles published during 2003 to 2007. Another important finding from this study is that there has been a shift in the topic of interest in science education researchers, where in 19982002, researchers were interested in the topic of concepts and changes in learning concepts, while in 2003 to 2007 researchers were interested in the topic of learning contexts. Lin et al. (2014) conducted a content analysis of the Research trend in science education from 2008 to 2012 in selected journals and have found that the top three research topics in published articles are the context of student learning, science teaching, and student conceptual learning. The most popular changes in research topics in the last 15 years also show a shift in journal preferences and the interests of researchers. For example, in 2003 to 2007, the context of student learning replaced student conceptual learning, which was the most widely published research topic from 1998 to 2002. Research topics in the context of student learning continued to rank first in 2008 to 2012.

There are several aspects of research methods that are often analyzed on content analysis, such as research methods and designs, and populations and samples. There are types of quantitative, qualitative and mixed method methods of research (Cresswel, 2014) and research and development (Richey et al., 2002; Haviz, 2013). At methodology of research, these methods are applied in several more detailed designs, such as quantitative, descriptive, correlation, causal-comparative, experimental, single subject. Qualitative consists of content analysis, narative, etnography, grounded theory, case study and phenomenographics. Mixed methods consist sequential, concurent, and transformative. Research and development (R \& D) or educational design research (EDR) consists of Plomp models (Plomp, 2010), 4-d (Thiagarahan et al., 1974) and Borg \& Gall models (Borg and Gall, 1989). According to Gay et al. (2011), population is all members of a specified group and samples in which subset of a population. Researchers in education can choose samples from students from elementary schools, junior high schools, high schools, colleges or even from educators or teachers (Calik \& Sozbilir, 2014). Preservice biology teachers also choose topics in biology learning to be used as the topic and subject matter of their research. Biology learning in Indonesia has many learning topics. This can be found in various biology source books used in Indonesian schools. The topic is the same as the biological topic written by Derman (2017). Some of these biology topics are Biology: Life Sciences (BLS), Cell (C), Genetics and Heredity (GH), Environmental Education (EE), Evolution (E), Tissues (Ts), System (Ss), Energy (Egy). These explanations also show a gap in research that aims to investigate research trends in biology education research at universities, which focus on identifying the distribution of BER sample on the thesis, BER method on the thesis, BER element on the thesis and BER topic and subject matters on the thesis of preservice biology teachers. 


\section{METHODS}

This study used content analysis. A framework for content analysis concist a few conceptual components: a body of text, the data that a content analyst has available to begin an analytical effort, a research question that the analyst seeks to answer by examining the body of text, a context of the analyst's choice within which to make sense of the body of text, an analytical construct that operationalizes what the analyst knows about the context, inferences that are intended to answer the research question, which constitute the basic accomplishment of the content analysis, and validating evidence, which is the ultimate justification of the content analysis (Krippendorff, 2004; Kaid, 1989). The population of this study was the theses of pre-service biology teacher from two universities, Department of Biology Education Universitas Negeri Padang, Indonesia (Bioedu UNP), and Department of Biology Education Institut Agama Islam Negeri, Indonesia (Bioedu IAIN BS). The thesis collected for analysis was thesis written from 2000 to 2017 by preservice biology teachers. The total number of them is 1347 theses (Bioedu UNP $=1100$ and Bioedu IAIN
$\mathrm{BS}=247$ theses). This study examines all the theses of the preservice teacher from two universities. There are differences in the base years of data collected. Bioedu UNP has held biology studies before 2000 and has more collections than Bioedu IAIN BS. Unlike Bioedu IAIN BS, this department was only established in 2008 and has only had a collection of thesis biology preservice teacher since 2012 .

This study uses the Conten Analysis Form (CAF) instrument (Derman, 2017). This instrument was modified according to research needs and adapted to biology learning in Indonesia, namely in the sample section, method, design and research element. Whereas changes in the biology subjects and subjects matters are not changed. In the sample section, the categories used were the Primary School (PS), Junior High School (JHS), Senior High School (SHS), Higher Education and others. In the method section, the categories used are Quantitative, Qualitative, Mixed Method, Research \& Development, and others. A complete description of the research instruments was written in Table 1.

Table 1. Content Analysis Form (CAF)

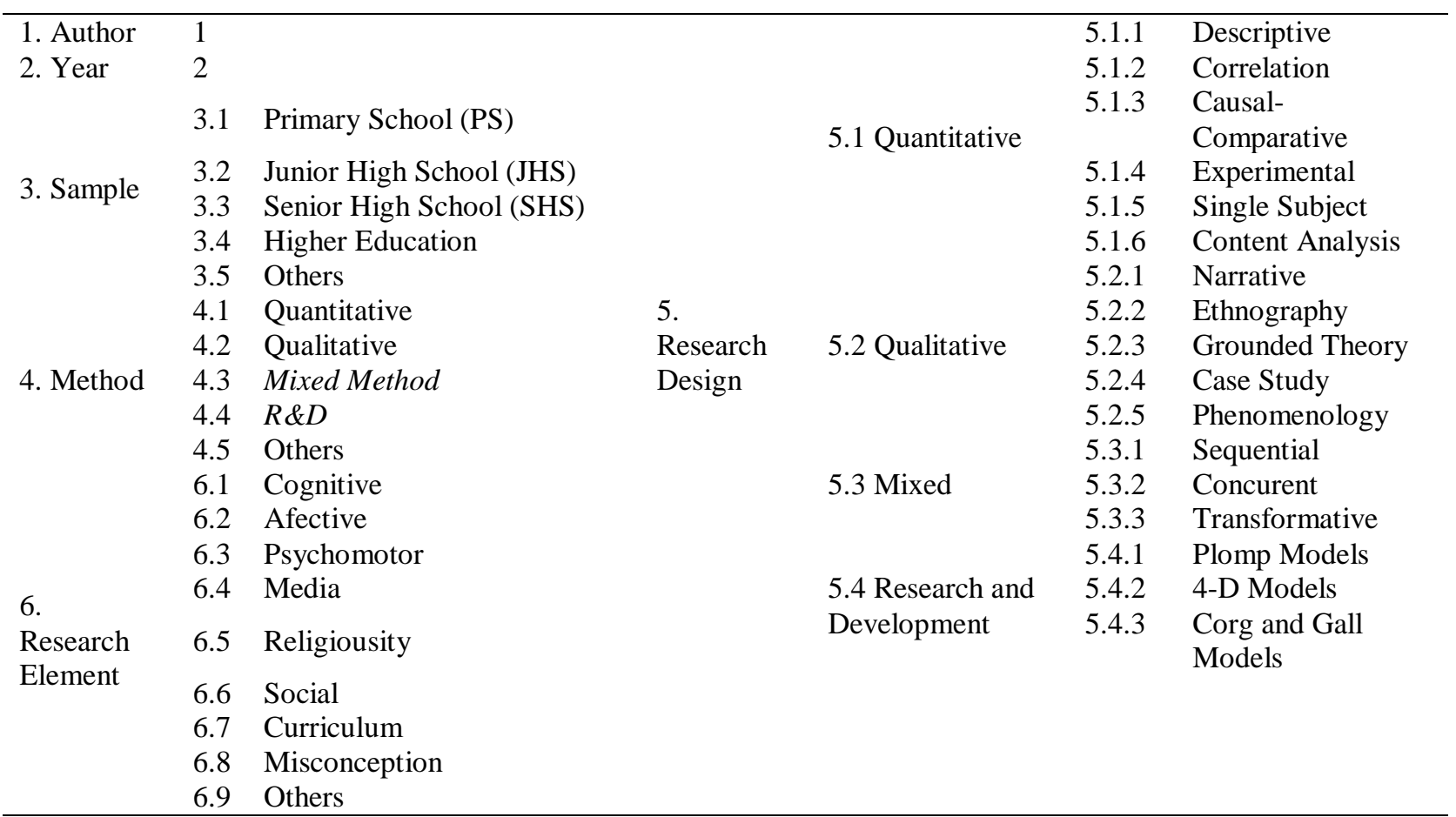




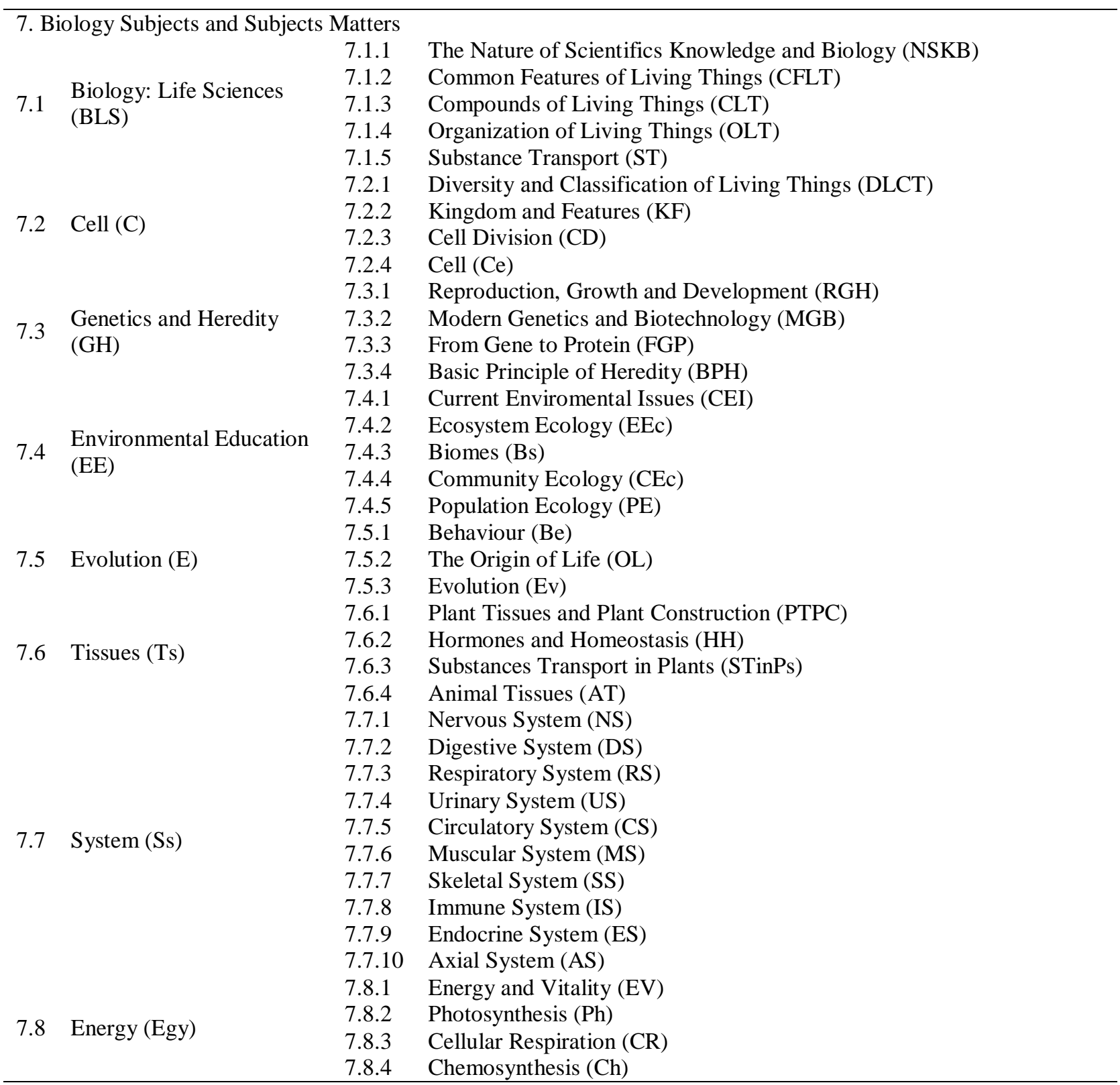

Data collection was conducted from October 2017 to March 2018. Data was collected from theses based on CAF indicators. Then do the coding. The purpose of the coding is to convert data in the form of letters into data in the form of numbers, data coding is done by preparing coding sheets first with Microsoft Excel by paying attention to the coding guidelines that have been compiled. All data that has been collected is combined in coding sheet. Descriptive statistics are used to analyze data that has been obtained previously. Data that has been obtained is presented in tables, graphs or diagrams. After the data is presented, it is necessary to interpret or interpret the data.

\section{RESULTS AND DISCUSSIONS}

The result of the study showed that the total number of them is 1347 theses (Bioedu $\mathrm{UNP}=1100$ and Bioedu IAIN BS $=247$ theses). The result of the study also showed that the highest number of theses of UNP bioedu biology teacher candidates was found in 2008, which were 141 theses and the least number of theses found in 2006 was 11 theses. The highest number of preservice teacher theses from the bioedu IAIN BS found in 2015 was 56 theses and the lowest number of theses was found in 2012, which were 20 theses. Complete data on distribution 


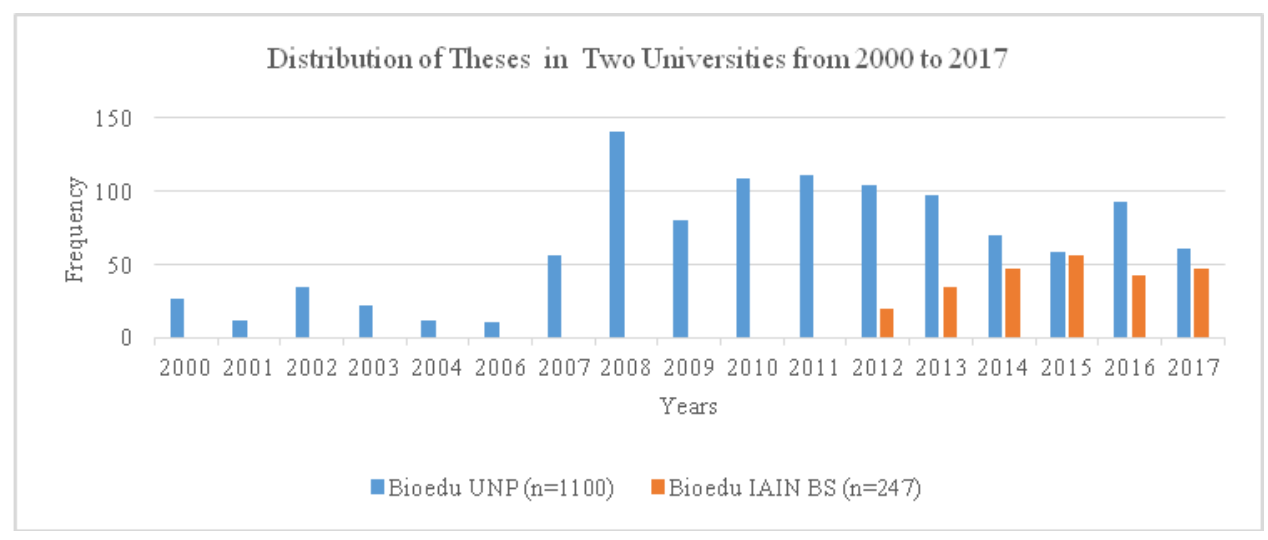

Figure 1. Distribution of Theses of Preservice Biology Teachers in Two Universities from 2000 to 2017

\section{Distribution of BER sample of the thesis of preservice biology teachers}

The results of the study of the Distribution of BER sample on thesis pre- service teachers from two universities are shown in Figure 2.

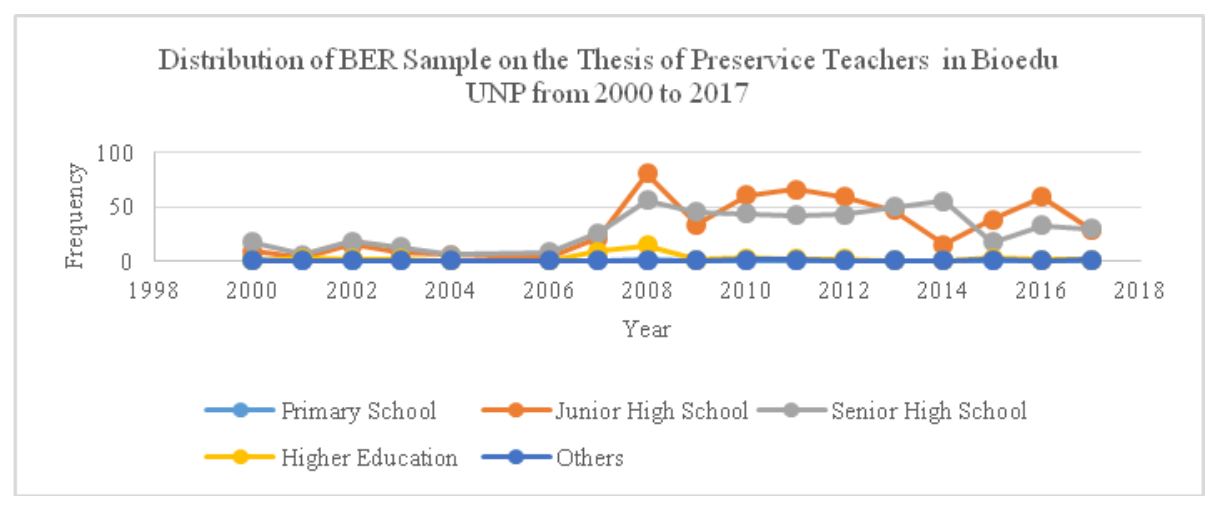

Figure 2. Distribution of BER Sample on the Thesis of Pre-service Teachers in Bioedu UNP from 2000 to 2017

The results in Figure 2 show that in the early 2000s it was seen that most preservice teachers at Bioedu UNP chose and used high school seniors as samples. The primary school is the least used sample in their study. Different results were found in the mid-2000s until the end of 2008 to 2017. The graph in Figure 2 shows that preservice teacher students from Bioedu UNP preferred junior high school as their sample, and primary schools were still the most little samplewas chosen and used in the study.
The results of the same study were also found at Bioedu IAIN Batusangkar. In 2012 to 2015, preservice teachers also chose and used the most high school seniors as the research sample. Different results were found in 20162017. This year preservice teachers at universities tend to choose junior high school as a research sample. The primary school became the least selected sample and was used in their study that can be seen in the figure 3 . 


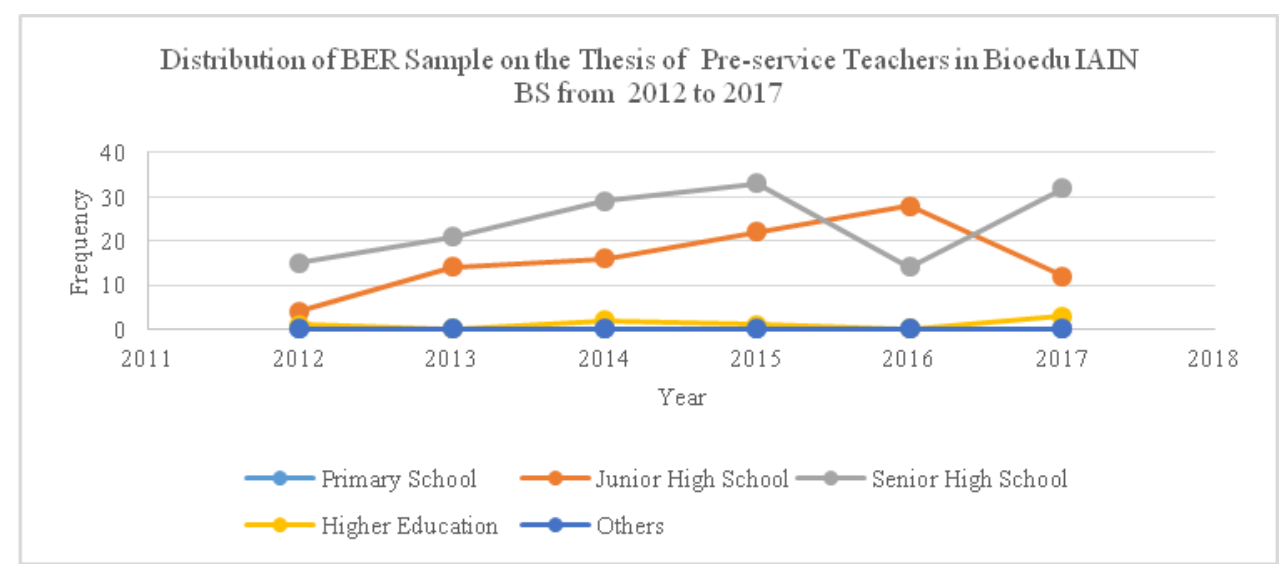

Figure 3. Distribution of BER Sample on the Thesis of Pre-service Teachers in Bioedu IAIN BS from 2012 to 2017

When data from these two universities are compared it can be seen that in 20002011, preservice teachers from bioedu unp preferred junior high school, which amounted to $47.15 \%$ or there were as many as 306 theses that included junior high school as a research sample. While primary school only found 2 theses. In 2012 to 2017, preservice biology teachers from Bioedu UNP still chose the highest and most high school as a research sample, and the least sample was higher education which was only $14 \%$ or only 7 theses containing higher education as samples research. Different results were found in bioedu IAIN BS, preservice teachers preferred and used high school seniors as samples compared to others. The thesis that contains senior high school as the research sample is 144 pieces or $22.05 \%$. Preservice biology teachers at this university choose and use higher edication as a research sample, which is found in 7 theses or $14 \%$. Research data on distribution of BER sample on thesis preservice teacher students in two universities from 2000 to 2017 are shown in Table 2.

Different results were found in bioedu IAIN BS, preservice teachers preferred and used high school seniors as samples compared to others. The thesis that contains senior high school as the research sample is 144 theses or $22.05 \%$. Preservice biology teachers at university choose and use higher edication as a research sample, which is found in 7 theses or $14 \%$. Research data on distribution of BER sample on thesis pre-service teacher students in two universities from 2000 to 2017 are shown in Table 2.

Table 2. Distribution of BER Sample on the Thesis of Preservice Teacher from 2000 to 2017

\begin{tabular}{lccccc}
\hline \multicolumn{1}{c}{ Year and Universitiy } & $\begin{array}{c}\text { Primary } \\
\text { School }\end{array}$ & $\begin{array}{c}\text { Junior High } \\
\text { School }\end{array}$ & $\begin{array}{c}\text { Senior High } \\
\text { School }\end{array}$ & $\begin{array}{c}\text { Higher } \\
\text { Education }\end{array}$ & Others \\
\hline Bioedu UNP 2000-2011 & $100(2)$ & $47.15(306)$ & $43.03(281)$ & $72(36)$ & $50(2)$ \\
Bioedu UNP 2012-2017 & 0 & $38.06(247)$ & $34.92(228)$ & $14(7)$ & $50(2)$ \\
Bioedu IAIN BS 2012- & 0 & $14.79(96)$ & $22.05(144)$ & $14(7)$ & 0 \\
2017 & * Frequency (f) was in parentheses. Percent (\%) was outsides of parentheses
\end{tabular}

\section{Distribution of BER methodof the thesis of preservice biology teachers}

The results of the study of the distribution of BER method on the thesis of pre-service teachers from two universities are shown in Figure 4. The results of the study show that quantitive is the trend method that is most often chosen and used by preservice teacher bioedu UNP when conducting research. Quantitative is a trend from 2000 to 2013, but after that year alternately quantitative with research and development dominates the method chosen and used by preservice biology teacher. Meanwhile, qualitative is the smallest method chosen and 
used by preservice biology teacher at this university.

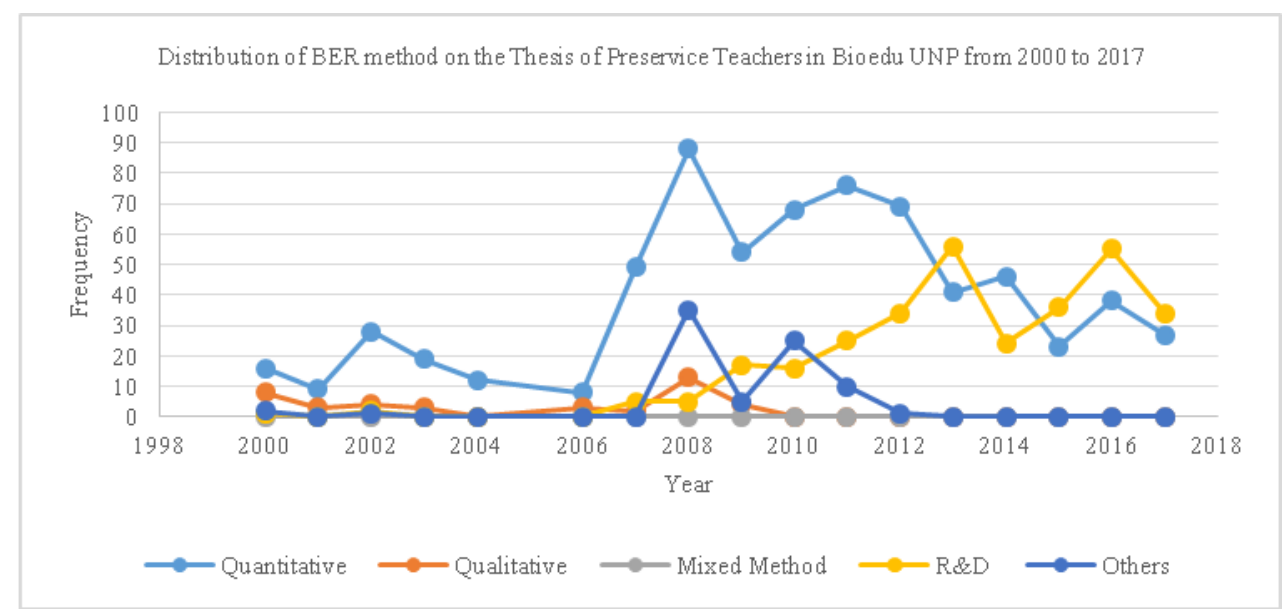

Figure 4. Distribution of BER Method on the Thesis of Pre-service Teachers in Bioedu UNP from 2000 to 2017

The results of the same study were also found at Bioedu IAIN Batusangkar. Preservice biology teachers from these universities have a tendency to choose and use quantitative as a research method in their thesis. These results were found in 2012 and 2013. In 2014 and 2015, research and development became the most used method and was chosen by Preservice biology teachers to conduct research. But in 2016 and 2017, quantitative returns are the most chosen method and used to conduct their thesis research. Whereas qualitative is the least chosen method and used to complete the thesis by preservice biology teachers from bioedu IAIN Batusangkar. These results can be seen and shown in Figure 5.

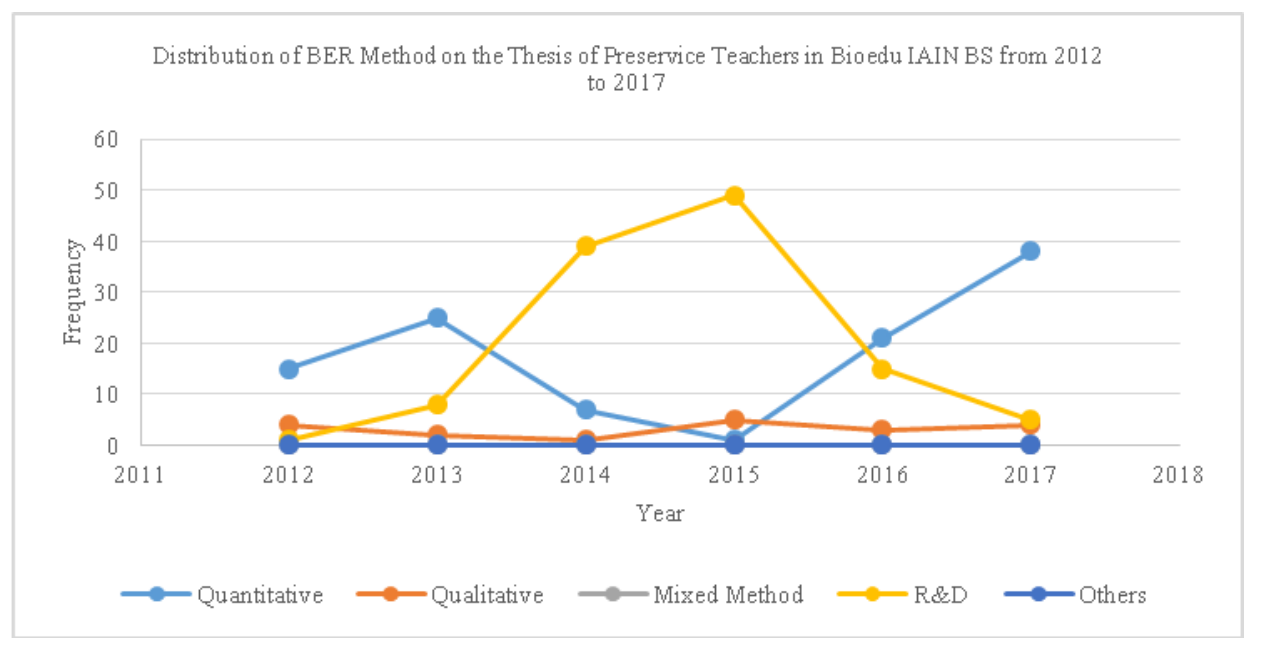

Figure 5. Distribution of BER Method on the Thesis of Preservice Teachers in Bioedu IAIN BS from 2012 to 2017

When the data of the two universities are compared, it can be seen that quantitative is the most chosen and used method by preservice biology teachers from bioedu UNP from 2000-2017. In 2000-2011, there were 427 theses or $54.88 \%$ of theses that chose and wrote quantiative as the method used when conducting research. And qualitative is the smallest method used by preservice biology teachers from bioedu UNP. The same results were also found in 2012 to 2017, there were 244 theses or $31.36 \%$ of theses that wrote 
quantiative as the method used when conducting research. And the other methods are the smallest. Throughout 2012 to 2107, the preservice biology teachers of Bioedu IAIN Batusangkar prefered research and development or/and educational design research as the most widely used methods. The number of theses using this method are
117 or $27.40 \%$. Qualitative is the least chosen method and used in the research conducted by these students. The number of theses that use this method are 19 or $32.21 \%$. Complete results of the distribution of BER method on thesis preservice teacher students from two universities across the year 2000-2017 are listed in Table 3.

Table 3. Distribution of BER Method on Thesis Pre-service Teacher from 2000 to 2017

\begin{tabular}{lccccc}
\hline \multicolumn{1}{c}{ University and Year } & Quantitative & Qualitative & $\begin{array}{c}\text { Mixed } \\
\text { Method }\end{array}$ & $\begin{array}{c}\text { R\&D or/and } \\
\text { EDR }\end{array}$ & Others \\
\hline Bioedu UNP 2000-2011 & $54.88(427)$ & $67.79(40)$ & 0 & $16.63(71)$ & $98.73(78)$ \\
Bioedu UNP 2012-2017 & $31.36(244)$ & 0 & 0 & $55.97(239)$ & $1.27(1)$ \\
Bioedu IAIN BS 2012-2017 & $13.75(107)$ & $32.21(19)$ & 0 & $27.40(117)$ & 0 \\
\hline * Frequency (f) was in parentheses. Percent (\%) was outsides of parentheses & & &
\end{tabular}

\section{Distribution of BER design of the thesis of preservice biology teachers}

Distribution of research design on the thesis of pre-service students from Bioedu UNP is shown in Table 4. The results of the study show that quantitative and research and development (R \& D) or/and educational design research (EDR) is the most chosen and used research design by preservice biology teachers from bioedu UNP. Some of the most preferred types of design by preservice biology teachers are descriptive and experimental (quantitative) and 4-D (Research and development (R \& D) or / and educational design research (EDR). While qualitative is only selected by preservice biology teachers from bioedu UNP on from 2000 to 2009. And the mixed method was never chosen by preservice biology teachers from Bioedu UNP to complete the writing of their thesis.

The same results were also found in preservice biology teachers from bioedu IAIN Batusangkar. The design chosen by many students is desciptive and experimental (quantiative), 4-D (Research and Development (R7D) or/and educational design research (EDR)). But at this university there were preservice biology teachers who chose to use the plomp model as their research method and design. As for qualitative, students only choose narrative in very low amounts. The same results as before, none of the mixed methods were chosen by preservice biology teachers from bioedu IAIN Batusangkar. Distribution of research design on thesis pre-service students on Bio Edu Batusangkar IAIN shown on Table 5.

Table 5. Distribution of Research Design on the Thesis of Preservice Biology Teachers in Bioedu IAIN Batusangkar

\begin{tabular}{|c|c|c|c|c|c|c|c|}
\hline \multicolumn{8}{|c|}{ Distribution of Research Design on Thesis Pre-service Students in Bioedu IAIN Batusangkar } \\
\hline Rese & Design & 2012 & 2013 & 2014 & 2015 & 2016 & 2017 \\
\hline \multirow{5}{*}{ Quantitative } & Descriptive & 0 & 0 & $2,128(1)$ & 0 & $2,38(1)$ & 5 \\
\hline & Correlation & 0 & 0 & 0 & 0 & 0 & 2 \\
\hline & Causal-comparative & 0 & 0 & 0 & 0 & 0 & \multirow{3}{*}{29} \\
\hline & Experimental & $35(7)$ & $34,3(12)$ & $4,26(2)$ & $1,79(1)$ & $26.2(11)$ & \\
\hline & Single subject & 0 & 0 & 0 & 0 & 0 & \\
\hline
\end{tabular}




\begin{tabular}{|c|c|c|c|c|c|c|c|}
\hline \multicolumn{2}{|c|}{ Research Design } & 2012 & 2013 & 2014 & 2015 & 2016 & 2017 \\
\hline \multirow{6}{*}{ Qualitative } & Content analysis & 0 & 0 & 0 & 0 & 0 & \\
\hline & Narative & $10(2)$ & $5,71(2)$ & 0 & 0 & 0 & \\
\hline & Etnography & 0 & 0 & 0 & 0 & 0 & \\
\hline & Grounded theory & 0 & 0 & 0 & 0 & 0 & \\
\hline & Case study & 0 & 0 & 0 & 0 & 0 & \\
\hline & Phenomenographics & 0 & 0 & 0 & 0 & 0 & \\
\hline \multirow{3}{*}{ Mixed Method } & Sequential & 0 & 0 & 0 & 0 & 0 & 2 \\
\hline & Concurent & 0 & 0 & 0 & 0 & 0 & \\
\hline & Transformative & 0 & 0 & 0 & 0 & 0 & \\
\hline \multirow{4}{*}{$\begin{array}{l}\text { Research and } \\
\text { develpoment (R7D) } \\
\text { or/and educational } \\
\text { design research } \\
\text { (EDR) }\end{array}$} & Plomp & 0 & $2,86(1)$ & $2,13(1)$ & $1,79(1)$ & 0 & 3 \\
\hline & $4-\mathrm{D}$ & $5(1)$ & $8,57(3)$ & $40,4(19)$ & $48,2(27)$ & $21,43(9)$ & 6 \\
\hline & Borg \& Gull & 0 & 0 & 0 & 0 & 0 & 0 \\
\hline & Total & 20 & 35 & 47 & 56 & 42 & 47 \\
\hline
\end{tabular}

\section{Distribution of BER element on the thesis of preservice teachers}

The results of the research on the distribution of BER elements of preservice biology teachers from two universities have been shown in Figure 6 and Figure 7. The results of the research shown that preservice biology teachers from bioedu UNP tend to choose cognitive as a research element from 2000 to 2014. From 2015 to 2017, learning media became the main choice as a research element that was chosen and used by preservice biology teachers. A cross the year 2000-2017, misconception was the smallest or least selected research element and was used by preservice biology teachers from bioedu UNP. Results about distribution of BER element on the thesis of preservice biology teachers from the Department of Biology Education UNP from 2000 to 2017 are shown in Figure 6.

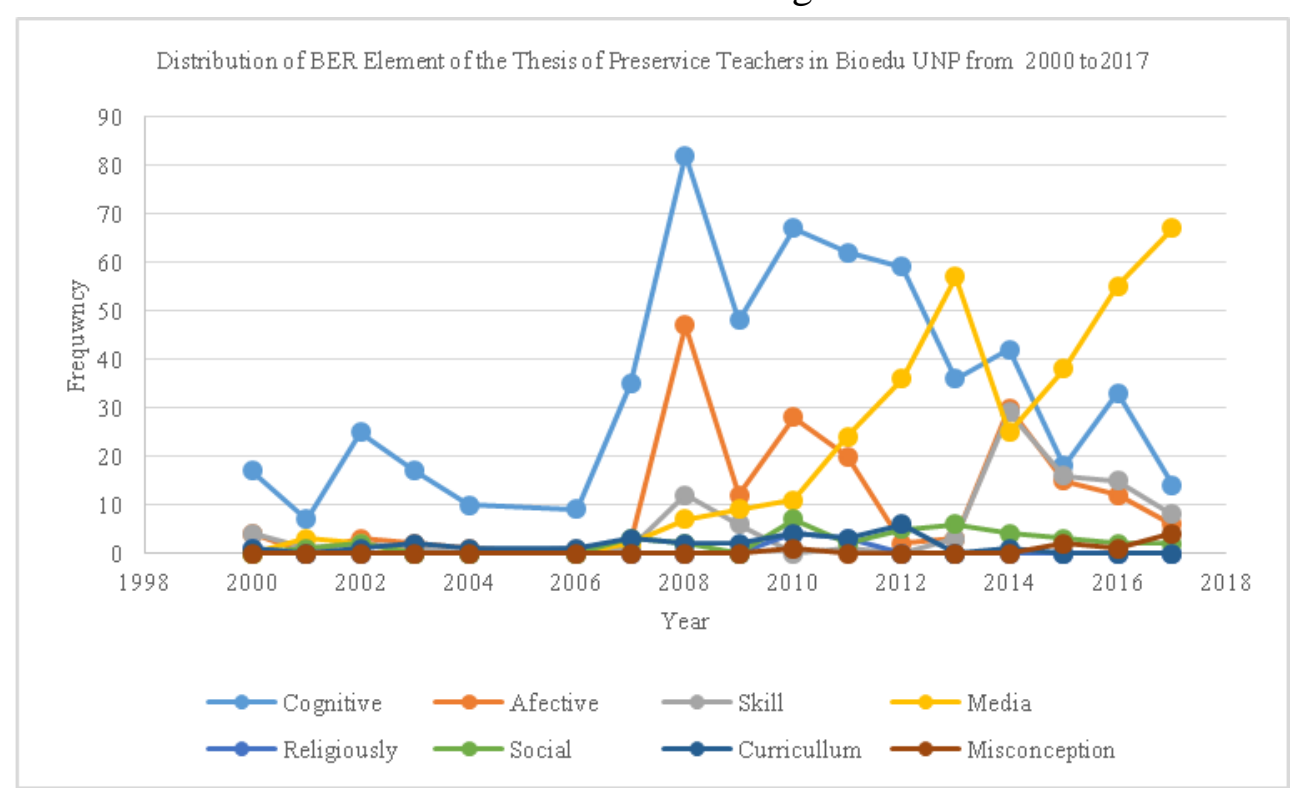

Figure 6. Distribution of BER Element of the Thesis of Preservice Teachers in Bioedu UNP from 2000 to 2017

The same results were also found in bioedu IAIN Batusangkar. In 2012 to 2013, preservice biology teachers at this university tended to choose and use cognitive as an elemet research. But in 2014 to 2015, learning media were mostly chosen and used by 
preservice biology teachers from bioedu IAIN Batusangkar. In 2016 and 2017, cognitive has again become the most important research element chosen and used by preservice biology teachers from bioedu IAIN Batusangkar. In 2012 to 2017, misconception became the least research element chosen and used by preservice biology teachers from bioedu IAIN Batusangkar. To omplete results about distribution of research elements on the thesis of preservice biology teachers from the Department of Biology Education in IAIN BS from 2012 to 2017 is shown in Figure 7.

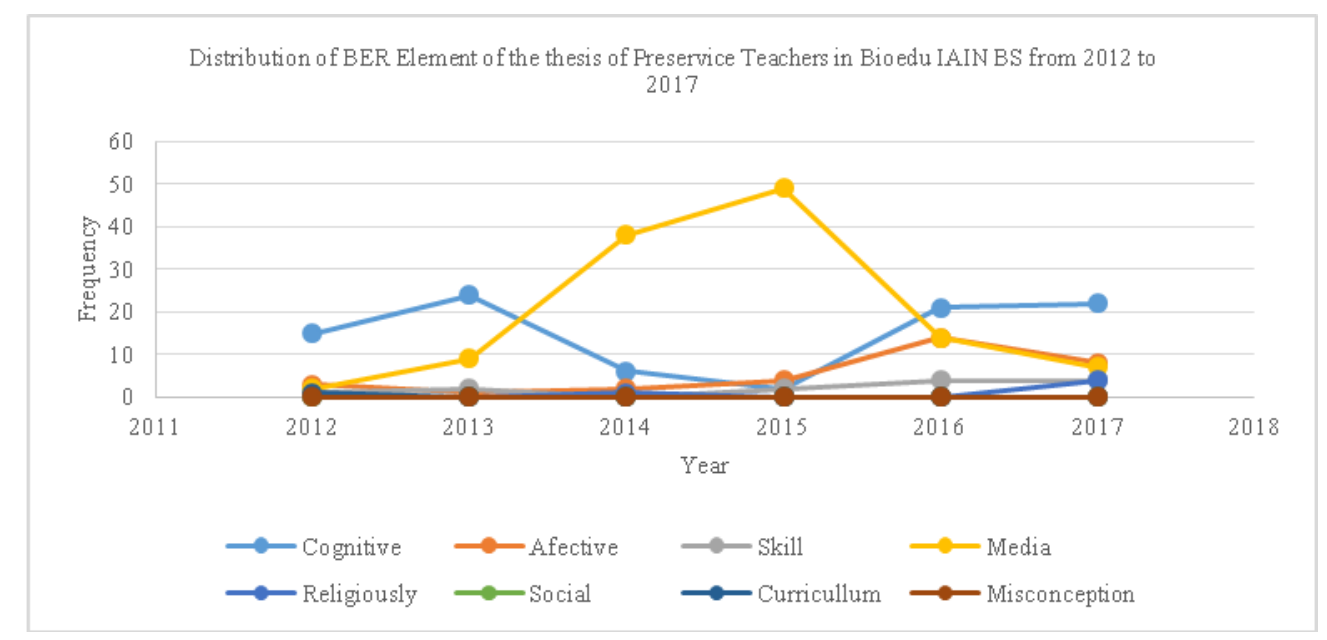

Figure 7. Distribution of BER Element of the Thesis of Preservice Teachers in Bioedu IAIN BS From 2012 to 2017

When data from these two universities are compared, it is seen that cognitive is the most chosen research element and used in student theses in these two universities. In 2000-2011, there were 379 theses or $56.48 \%$ preservice biology teachers from Bioedu UNP which contained cognitive as a research element. In 2012-2017, there were 202 theses or $30.11 \%$ preservice biology teachers from
Bioedu UNP which contained cognitive as a research element. There are 90 theses or $13.41 \%$ preservice biology teachers from Bioedu IAIN Batusangkar which contain cognitive as a research element. The results of the study of distribution of BER elements of the preservice biology teachers in two universities from 2000 to 2017 were written in Table 6.

Table 6. Distribution of BER Element of the Thesis of Pre-service Biology Teachers in Two Universities from 2000 to 2017

\begin{tabular}{|c|c|c|c|c|c|c|c|c|}
\hline \multirow[b]{2}{*}{ Universities } & \multicolumn{8}{|c|}{ Research Element } \\
\hline & $\begin{array}{c}\text { Cognitiv } \\
\mathrm{e}\end{array}$ & $\begin{array}{c}\text { Afectiv } \\
\mathrm{e}\end{array}$ & Skill & $\begin{array}{l}\text { Medi } \\
\text { a }\end{array}$ & $\begin{array}{c}\text { Religious } \\
\text { ly }\end{array}$ & Social & $\begin{array}{l}\text { Curri } \\
\text { cullum }\end{array}$ & $\begin{array}{c}\text { Mis } \\
\text { conceptio } \\
n\end{array}$ \\
\hline $\begin{array}{l}\text { Bioedu UNP } \\
2000-2011\end{array}$ & $\begin{array}{l}56.48 \\
(379)\end{array}$ & $\begin{array}{l}31.40 \\
(119)\end{array}$ & $\begin{array}{c}25.6 \\
6 \\
(29)\end{array}$ & $\begin{array}{c}12.75 \\
(58)\end{array}$ & $\begin{array}{c}61.54 \\
(8)\end{array}$ & $\begin{array}{c}43.59 \\
(17)\end{array}$ & $\begin{array}{l}71.43 \\
(20)\end{array}$ & $\begin{array}{l}12.5 \\
(1)\end{array}$ \\
\hline $\begin{array}{l}\text { Bioedu UNP } \\
\text { 2012-2017 }\end{array}$ & $\begin{array}{l}30.11 \\
(202)\end{array}$ & $\begin{array}{c}31.05 \\
(68)\end{array}$ & $\begin{array}{c}62.8 \\
3 \\
(71)\end{array}$ & $\begin{array}{l}61.10 \\
(278)\end{array}$ & 0 & $\begin{array}{l}56.41 \\
(22)\end{array}$ & $\begin{array}{l}25 \\
(7)\end{array}$ & $\begin{array}{c}87.5 \\
(7)\end{array}$ \\
\hline $\begin{array}{l}\text { Bioedu IAIN } \\
\text { BS 2012-2017 }\end{array}$ & $\begin{array}{c}13.41 \\
(90)\end{array}$ & $\begin{array}{c}14.61 \\
(32)\end{array}$ & $\begin{array}{c}11.5 \\
1 \\
(13)\end{array}$ & $\begin{array}{l}26.15 \\
(119)\end{array}$ & $\begin{array}{l}38.46 \\
(5)\end{array}$ & 0 & $\begin{array}{l}3.57 \\
(1)\end{array}$ & 0 \\
\hline
\end{tabular}


Distribution of BER topic and subject matters of the thesis of preservice biology teachers

The results of the research on the distribution of topics and subject matters of the thesis of preservice biology teachers from two universities are shown in Figures 8, 9, and 10.

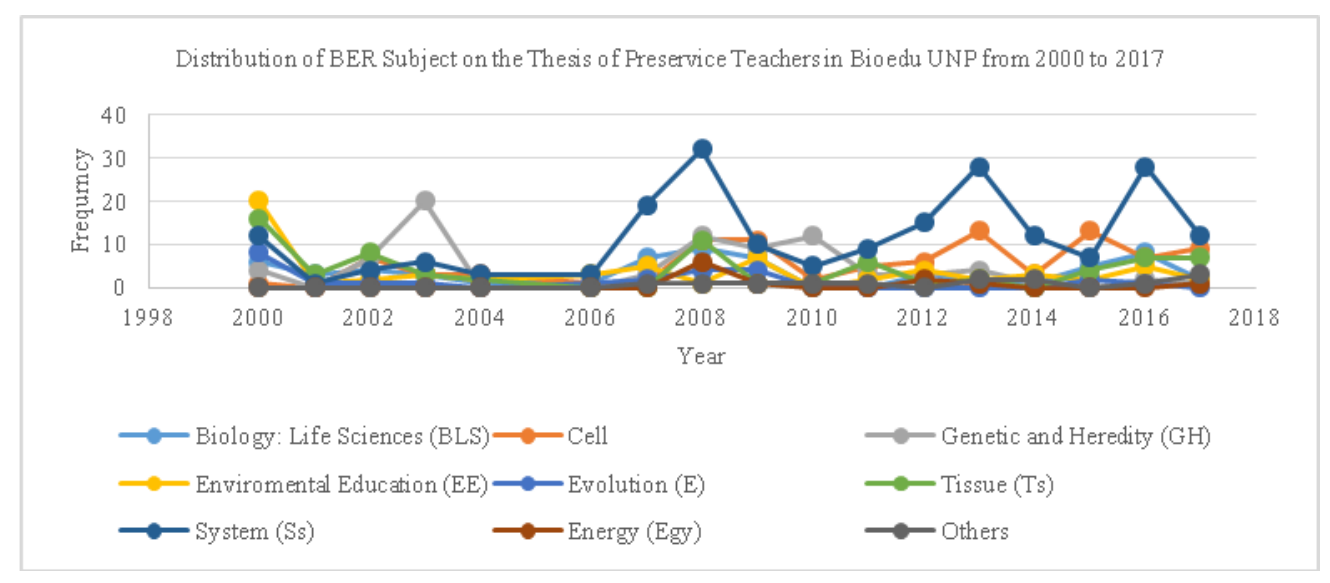

Figure 8. Distribution of BER Subject of the Thesis Preservice Biology Teachers in Bioedu UNP from 2000 to 2017

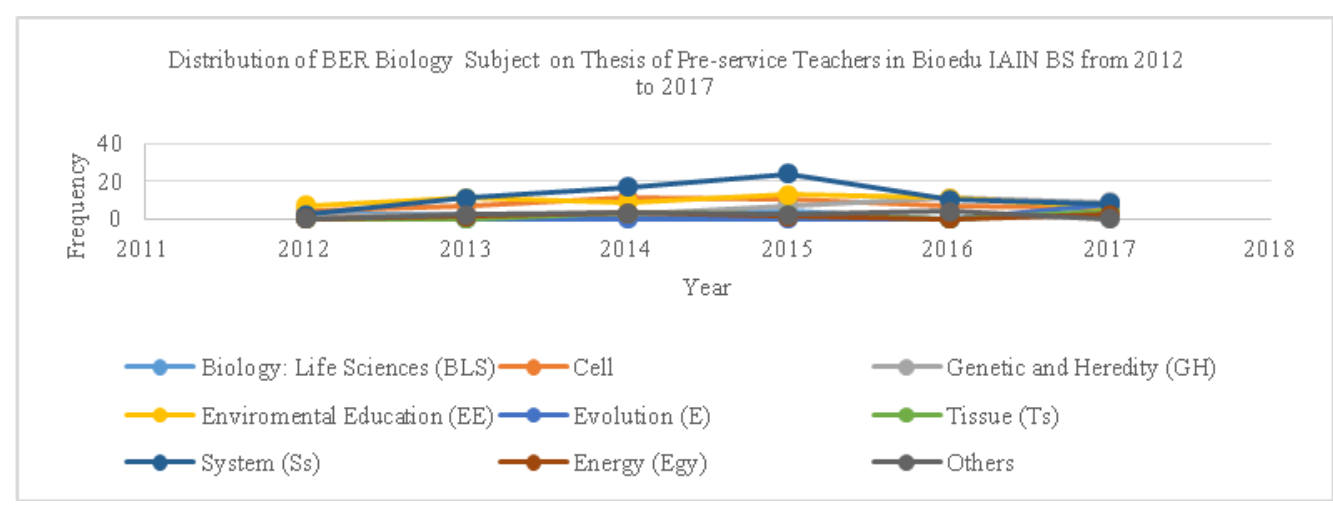

Figure 9. Distribution of BER Subject of the Thesis Preservice Teachers in Bioedu IAIN BS from 2012 to 2017

Based on Figure 8, in 2000 the environmental education became the most preferred biology topic by preservice biology teachers from bioedu UNP. There are 20 theses that contain environmental education in the thesis, followed by tissue (Ts) of 16 theses. The least biological subject is cell, which is only 1 thesis that contains the topic. Over the next two years, the distribution of biological uses of the subject was distributed equally. In 2003, there was a surge in the use of the topic of genetic and heredity. The surge in topic use System (Ss) occurred in 2008, 2013 and 2016. While the topic of energy became a biology topic that was always not in demand by preservice biology teachers from Bioedu UNP.

Distribution of BER subject on thesis of the pre-service biology teachers from Department of Biology Education IAIN BS from 2012 to 2017 can be seen in Figure 9. In 2012, the topic of environmental education (EE) became a biology topic in the research that was most in demand by preservice biology teachers from Bioedu IAIN Batusangkar, because there were 7 of 14 theses that contained the topic. In 2013, a 
surge in System (Ss) topic usage began. There were 11 theses from 35 theses which contained the topic. The surge in topic usage of System (Ss) continued in 2014 and 2015. But the topic of System (Ss) decreased in knowing 2016 and the topic of Cell became the most chosen by preservice biology teachers from bioedu IAIN Batusangkar. Similar results were also found in 2017; the Cell became the most chosen biology topic and was used as a research topic by preservice biology teachers from bioedu IAIN Batusangkar.

When the data from these two universities is compared it can be seen that the topics most in demand by the pre service biology teachers are spread evenly. On the topic of Biology: Life Sciences (BLS), many pre-service biology teachers chose The Nature of Scientific Knowledge and Biology (NSKB) and the Common Features of Living Things (CFLT) as the subject matter of their research. On the topic of Cell (C), many pre service biology teachers chose Kingdom and Features (KF) as the subject matter of their research. In the topic of Genetics and Heredity $(\mathrm{GH})$, pre- service biology teachers chose Reproduction, Growth and Development (RGH) and Modern Genetics and Biotechnology (MGB) as the subject matter of their research. On the topic of Environmental Education (EE), many preservice biology teachers chose Current Environmental Issues (CEI) and Ecosystem Ecology (EEc) as the subject matter of their research. On the topic of Evolution (E), many pre service biology teachers chose Behavior (Be) and The Origin of Life (OL) as the subject matter of their research. On the topic of Tissues (Ts), many pre service biology teachers chose Plant Tissue and Plant Construction (PTPC) and Substances Transport in Plants (STinPs) as the subject matter of their research. On the topic of System (Ss), many pre service biology teachers choose Digestive System (DS) and Circulatory System (CS) as the subject matter of their research. On the topic of Energy (Egy), pre service biology teachers have chosen Photosynthesis $(\mathrm{Ph})$ as the subject matter of their research. Distribution of BER subject matters from the thesis of presenter teacher from two universities across the year 2000-2017 shown on Figure 10.

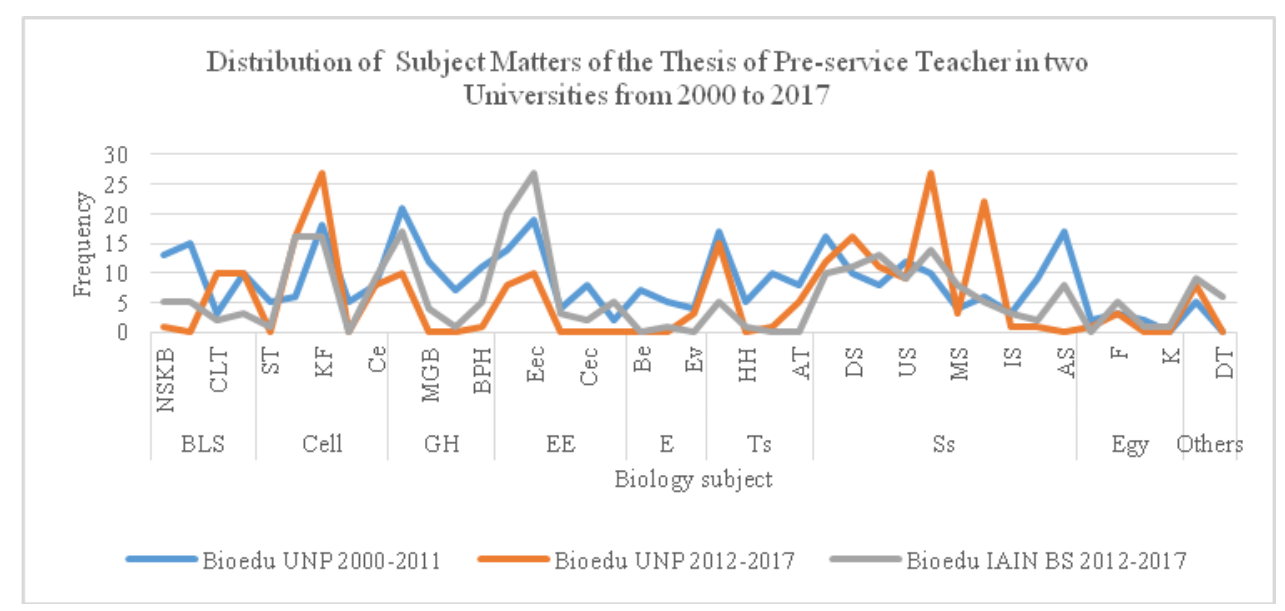

Figure 10. Distribution of BER Subject Matters of the Thesis of Pre-service Teacher from 2000 to 2017

This study investigated the tendency of the preservice biology teacher in choosing research samples, the research methods used, the research designs used and the elements traced and the biological material chosen in the research they had done. There are several reasons that can be understood to explain the research trends of preservice biology teachers.

The results of this study show that there are various types of samples which are usually used as research samples in biology learning. The samples are educators, students 
and education staff in elementary, secondary and tertiary schools. This research has also grouped five samples that will be chosen by preservice teacher, namely elementary, junior high, high school, university and others. The results of the study show that the research samples selected by the pre-service biology teachers of the two universities tend to choose research samples at the junior and senior high school level.Preservice biology teachers choose junior high and high school as research samples because biology subjects are more studied in middle and high school. At the elementary level biology topics are not specifically studied. This finding is in accordance with the findings of the research conducted by Derman (2017), that secondary school is one of the sample studies which is mostly preferred by researchers in science or biology learning. The findings of this study are also in accordance with the results of the study reported by Gul \& Sozbilir (2015), that the number of biology study hours is greater in secondary schools, so researchers tend to choose secondary schools as their research sample.

Regarding the findings of the study on the use of secondary schools as the main sample of research, there are other arguments that can be written. The argument is obtained from the results of previous studies. Previous researcher such as Cimer (2012), Fonseca et al. (2012), Reiss \& Tunnicliffe (2011), Usak et al. (2009), Yesilyurt \& Gull (2012) have revealed that preservice teachers or the teacher still has limited knowledge, learning difficulties, misunderstandings, negative attitudes and so on in some biological material. So that the existence of these problems needs to be done research and take samples of research in schools that have biology learning such as junior high and high school.

In several baboon books on educational research methods have been written that there are research methods used to conduct research, namely quantitative, qualitative and mixed methods (Cresswel, 2014; Gay et al., 2011). But not only that, research and development and/or educational design research (Haviz, 2013) are the methods that are chosen and carried out by pre-service biology teachers. Thus, quantiative and $\mathrm{R} \&$ $\mathrm{D}$ or/and EDR are the two methods that are mostly chosen and used by the pre service biology teachers in conducting their research.

Quantitative methods and $\mathrm{R} \& \mathrm{D}$ or/and EDR are seen as easy to implement in the world of education. Calik et al. (2008) have explained that quantitative methods are preferred in research, because this method is easier to express statistics and compare with past data (Derman, 2017). Another reason is that it is very well understood that Quantitative is research conducted by collecting data in the form of numbers, or data in the form of words or sentences that are converted into numbers in the form of data. The data in the form of numbers are then processed and analyzed to obtain a scientific information behind these figures by analyzing using statistics (Martono, 2016; Creswell, 2014; Sugiyono, 2013) Quantitative research can be used if the problem which is the starting point of research is clear, researchers want to get extensive information from a population, researchers want to know the effect of certain treatments on others, researchers intend to test the research hypothesis, researchers want to get accurate data based on empirical and measurable phenomena, and researchers want to test for the presence of clutter the question of the validity of certain knowledge, theories and products (Sugiyono, 2013). The characteristics of quantitative research are data in the form of numbers, there are hypotheses and procedures, the use of controls to minimize factors that can disrupt the results of research, a large number of research subjects, objects of research with separate researchers and using written tests, questionnaires and others .

While development research is a systematic study of the process of designing, developing and evaluating models, programs, teaching-learning strategies and their tools, products and systems as solutions to complex 
problems in practical education, and also has the aim of increasing knowledge about the characteristics of the model, programs, teaching-learning strategies and their tools, products and systems (Haviz, 2013). The characteristics of development research are: first, the existence of intervention (intervention) when designing research objectives. Second, there is a cycle of analysis, design and development, evaluation and revision. The third involvement of practitioners is the active participation of practitioners at each stage and research activities. Fourth, process oriented which aims to understand and improve product quality. Fifth, user-oriented, namely improving the quality of design with the practicalisation process by users in the field, and sixth, theory-oriented, namely design carried out based on conceptual frameworks and theories, supported by in-depth evaluation of products (Haviz, 2013). In this study, this development research method was also used by pre service biology teachers to develop media as a means to support learning, due to the lack of media in schools. This condition causes pre service biology teachers to choose this development method in the study.

Two other research methods commonly used in the world of education are qualitative and mixed methods. Both of these methods are not selected by pre service biology teachers to do their research. It is suspected that many students are not interested in doing so because in quantiative there are no hypotheses that guide researchers, general problems are known as shadows of issues of concern, problems and tends to develop during research as understanding the context of research and participants deepening, phenomena examined because they are in natural context and they have seen from the sample / participants, there are some participants involved in the research, data analysis is a natural interpretation, and there is interaction between researchers and participants. While mixed method is considered difficult to do by pre service biology teachers because it is a research approach that combines or associates qualitative forms and quantitative forms. This approach involves philosophical assumptions, the application of qualitative and quantitative approaches, and mixing the two approaches into one study. This approach is more complex than just collecting and analyzing two types of data, this method also involves the function of the two research approaches collectively so that the strength of this research as a whole is greater than qualitative and quantitative research (Creswell, 2014).

There are several elements that are usually traced in student research including cognitive, affective, psychomotor, media, social values, religious values, curriculum, and misconceptions and so on. This is based on the basic principle of learning, namely developing the potential of students (cognitive, affective, psychomotor), or in the new paradigm known as the term intellectual, emotional, spiritual and skill intelligence optimally (Lufri, 2007; Rustaman et al., 2003). Each of these aspects is traced because there are several problems, for example the low learning outcomes, the attitude of students who are not good in the learning process, the skills of teachers who lack teaching, limited media in learning, always changing curriculum, student misconception in learning, religious and social aspects that are very influential on the teaching and learning process, and others.

The findings of this study show that the tendency of biological material selected in research by pre service biology teachers is biological material that examines the system of the human body or human physiology. The trend of students choosing this topic is because the number of preliminary findings before the research conducted by preservice biology teacher students shows that the low learning outcomes of students in junior high school or high school in the body system material. This condition is the main reason for the pre service biology teachers to choose the topic of the body system. Even though there are other findings that show there are also students in junior and senior high schools getting low scores on other biology topics. 
The difficulties of middle/high school students in Indonesia master the material of the system because this material contains facts and processes (Haviz, 2018a; Haviz, 2018b).

Finally, biology education research is closely related to research in science learning. Educational research can use a qualitative, quantitative, naturalistic approach. Research in science education can also use methods of development, research and development $(\mathrm{R} \&$ D), mixed methods, descriptive, survey, field, case studies and others. Science learning research in addition to revealing misconceptions, conceptual changes, social constructivism in terms of scientific concepts, can be integrated with insertion and the planting of scientific values in it. The values in question include moral values, practical values, intellectual values, religious values, socio-economic values and the value of education (Rustaman, 2012).

\section{CONCLUSION AND RECOMMENDATION}

The study provides several conclusions, the thesis collected for analysis was thesis written from 2000 to 2017 by preservice biology teachers. The total number of them is 1347 theses (Biologi education Universitas Negeri Padang Indonesia $=1100$ and Biologi education Institut Agama Islam Negeri Batusangkar Indonesia $=247$ theses).Distribution of BER sample has shown that junior and high school become the highest trend sample and are chosen by pre service biology teachers. Distribution of BER method has shown that quantitative and research and development or educational research is the trend of the most chosen and conducted methods by pre service biology teachers.

The Distribution of BER element has shown that cognitive and learning media are the trend of the most trendy research elements chosen and carried out by pre service biology teachers.Distribution of BER topic and subject matters has shown that system and cell become the trend of biology topic and
Digestive System (DS) and Circulatory System (CS) and Features (KF) as the trend subject matter that is most chosen and performed by pre service biology teachers.Distribution of BER design has shown that descriptive, experimental (quantitative) and 4-D (Research and development (R \& D) or / and educational design research (EDR) became a design trend chosen and performed by pre service biology teachers.

\section{REFERENCES}

Borg, W. R., dan Gall, M. R., 1989.Education Research. New York: Longman.

Çalık, M., \& Sözbilir, M. (2014). Parameters of content analysis. Education and Science,39(174), 33-38. doi: 10.15390/EB.2014.3412

Çalık, M., Ünal, S., Coştu, B., \& Karataş, Ö. F. (2008). Trends in Turkish Science Education.Essays in Education, 23-45, (Special Edition)

Çimer, A. (2012). What makes biology learning difficult and effective: Students' views.Educational Research and Reviews, 7(3), 61-71. doi: 10.5897/ERR11.205

Chang, Y. H., Chang, C. Y., \& Tseng, Y. H. (2010). Trends of science education research: An automatic content analysis. Journal Science Education Technology, 19, 315-331.

Creswell, J. W. (2014). Research Design: Qualitative, Quantitative and Mixed Methods Approaches (4th ed.). Thousand Oaks, CA: Sage.

Derman, M. (2017). Biology education research in Turkey: Trend form 1989 to 2015. Journal of Turkish Science Education, 14, 89-109.

Elo, S., \& Kyngas, H. (2008). The qualitative content analysis process. Journal of advanced nursing, 62, 107-115. 
Fonseca, M. J., Costa, P., Lencastre, L., \& Tavares, F. (2012). Multidimensional analysis of highschool students' perceptions about biotechnology. Journal of Biological Education, 46(3), 129-139. doi:10.1080/00219266.2011.634019

Gay, L.R., Miles, G.E and Airasian, P. (2011). Educational Research: Competencies for Analysis and Applications. (10th Edition). Pearson EducationInternatioanl, Boston.

Gul, S., \& Sozbilir, M. (2015). Biology education research in Turkey. Eurasia Journal of Mathematics Science \& Technology Education, 11, 93-109.

Haviz, M, Adripen, Lufri, David, Maris I. M., \& Fudholi, A. (2019). Assessing preservice teachers' perception on $21^{\text {st }}$ century skills in Indonesia. Journal ofTurkish Science of Education (in review).

Haviz, M. (2013). Research and development: Penelitian di bidang kependidikan yang inovatif, produktif dan bermakna. Ta'dib, Volume 16, No. 1, 28-43.

Haviz, M. (2015). Cooperative learning model on developmental of biology. American Journal of Educational Research, 3(10), 1298-1304. doi:10.12691/education-3-10-14

Haviz, M. (2016). Designing and developing the integrated learning model on embryology. Transylvanian Review, 24-7. Retrieved from http://transylvanianreviewjournal.org/i ndex.php/TR/article/view/2998

Haviz, M. (2018a). Development of researchbased learning model in biology education: What is relevance, concystency and practicality? Journal of Education and Learning (EduLearn), 12(1), 143-149. doi:10.11591/edulearn.v12i1.6555
Haviz, M. (2018b). Computer-assisted biology learning materials: Designing and developing an interactive $\mathrm{CD}$ on spermatogenesis. IOP Conf. Series: Mater. Sci. Eng. 335, 012081, pp. 1-7. doi:10.1088/1757-899X/335/1/012081

Haviz, M. (2019). Teaching embryology through jigsaw cooperative learning. Journal of Baltic Science Education (in review).

Haviz, M., \& Maris, I. (2018). Teaching quantitative research method with three methods of learning. Al-Ta'lim Journal, 25(3). doi:http://dx.doi.org/10.15548/jt.v25i3 .394

Haviz, M., Karomah, H., Delfita, R., Umar, M. I., \& Maris, I. M. (2018). Revisiting generic science skills as 21 st century skills on biology learning. Jurnal Pendidikan IPA Indonesia, $\quad 7(3), \quad 355-363$. doi:10.15294/jpii.v7i3.12438.

Haviz, M., Novita, N., \& Helmitha, R. (2018). Designing and developing teaching material of human anatomy with thinking map: what is internal relevance and consistency? Edusains, 10(1), 38-45.

Hsieh, H. F., \& Shannon, S. E. (2005). Three Approaches to Qualitative Content Analysis. Qualitative Health

Kaid, L. L. (1989). Content analysis. In P. Emmert \& L. L. Barker (Eds.), Measurement of communication behavior (pp. 197-217). New York: Longman.

Kondracki, N. L., \& Wellman, N. S. (2002). Content analysis: Review of methods and their applications in nutrition education. Journal of Nutrition Education and Behavior, 34, 224-230.

Krippendorff, K. 2004. Content analysis: an introduction

to

its 
methodology( $2^{\text {nd }}$ Edition). London, Sage Publications, Inc.

Lee, M. H., Wu, Y. T., \& Tsai, C. C. (2009). Research trends in science education from 2003 to 2007: A content analysis of publication in selected journals. International Journal of Science Education, 31, 1999-2020.

Lin, C. T., Lin, J. T., \& Tsai, C. C. (2014). Research trend in science education from 2008 to 2012: Asystematics content analysis of publication in selected journals. International Journal of Science Education, 36, 1346-1372.

Lufri. (2007). Strategi pembelajaran biologi. Padang: UNP Press.

Martono, N. (2016). Metode penelitian kuantitatif: Analisis isi dan analisis data sekunder-Edisi revisi 2. Jakarta: RajaGrafindo Persada.

Plomp, T. (2010). Educational design research: As introduction. Dalam Tjeer Plomp and Nieeveen (Ed). An introduction to educational design research (p:9-35). Netherlands: www.slo.nl/organisatie/international/pu blications.

Reis, M. J. \& Tunnicliffe, S. D. (2011). Students' understandings of human organs and organsystems. Research in Science Education, 31, 383-399. doi: 10.1023/A:1013116228261

Richey, R. C., Klein, J. D., \& Nelson, W. A. (2002). Developmental research: Studies of instructional design and development.

Rustaman, N. Y. (2012). Trend penelitian pendidikan: Kasus penelitian pendidikan sains. Proceding Seminar Nasional Pendidikan IPA Tahun 2012 (pp. 1-13). Bandung: Universitas Pendidikan Indonesia.

Rustaman, N. Y., Dirdjosoemarto, S., Yudianto, S. A., Achmad, Y., Subekti,
R., Rochintaniawati, D., et al. (2003). Common textbook (Edisi revisi): Strategi belajar mengajar biologi. Bandung: Jurusan Pendidikan Biologi FMIPA UPI Bandung.Sugiyono. (2013). Metode penelitian kuantitatif kualitatif dan $R \& D$. Bandung: Alfabeta.

Thiagarajan, S., Semmel D, S., \& Semmel, M.I. (1974). Instructional Development for Traning of Exceptional Children A Source Book. Center for Innovation in Teaching the Handicapped Indiana University Bloomington Indiana.

Tsai, C. C., \& Wen, L. M. (2005). Research and trend in science education from 1998 to 2002. International Journal of Science Education, 27, 3-14.

Usak, M., Erdogan, M., Prokop, P., \& Ozel, M. (2009). High school and university students'knowledge and attitudes regarding biotechnology. Biochemistry and Molecular BiologyEducation, 37(2), 123-130. doi: 10.1002/bmb.20267.

Yeşilyurt, S., \& Gül, Ş. (2012). Ortaöğretim öğrencilerinin taşıma ve dolaşım sistemleri ünitesiile ilgili kavram yanılgilar1 [Secondary school students' misconceptions about the "transportation and circulatory systems" unit]. Kuramsal Eğitimbilim Dergisi, 5(1), 1748. 